Review

\title{
Precision Agriculture for Resource Use Efficiency in Smallholder Farming Systems in Sub-Saharan Africa: A Systematic Review
}

\author{
Cecilia M. Onyango ${ }^{1, *(\mathbb{C})}$, Justine M. Nyaga ${ }^{2}\left(\mathbb{D}\right.$, Johanna Wetterlind ${ }^{3}\left(\mathbb{D}\right.$, Mats Söderström ${ }^{3}(\mathbb{D}$ \\ and Kristin Piikki ${ }^{3,4}$ (D) \\ 1 Department of Plant Science and Crop Protection, University of Nairobi, P.O. Box 29053-00625, \\ Nairobi 00625, Kenya \\ 2 Department of Biological Sciences, University of Embu, P.O. Box 6-60100, Embu 60100, Kenya; \\ nyagajm@gmail.com \\ 3 Department of Soil and Environment, Precision Agriculture and Pedometrics, Swedish University of \\ Agricultural Sciences, P.O. Box 234, 53223 Skara, Sweden; johanna.wetterlind@slu.se (J.W.); \\ mats.soderstrom@slu.se (M.S.); kristin.piikki@slu.se (K.P.) \\ 4 The Alliance of Bioversity International and the International Center for Tropical Agriculture (CIAT), \\ c/o ICIPE-International Centre of Insect Physiology and Ecology, Duduville Campus Off Kasarani Road, \\ P.O. Box 823-0062, Nairobi 0062, Kenya \\ * Correspondence: ceciliam.onyango@gmail.com or cecilia.onyango@uonbi.ac.ke
}

Citation: Onyango, C.M.; Nyaga, J.M.; Wetterlind, J.; Söderström, M.; Piikki, K. Precision Agriculture for Resource Use Efficiency in Smallholder Farming Systems in Sub-Saharan Africa: A Systematic Review. Sustainability 2021, 13, 1158. https://doi.org/10.3390/su13031158

Received: 4 December 2020

Accepted: 18 January 2021

Published: 22 January 2021

Publisher's Note: MDPI stays neutral with regard to jurisdictional claims in published maps and institutional affiliations.

Copyright: (c) 2021 by the authors. Licensee MDPI, Basel, Switzerland. This article is an open access article distributed under the terms and conditions of the Creative Commons Attribution (CC BY) license (https:// creativecommons.org/licenses/by/ $4.0 /)$.

\begin{abstract}
Opportunities exist for adoption of precision agriculture technologies in all parts of the world. The form of precision agriculture may vary from region to region depending on technologies available, knowledge levels and mindsets. The current review examined research articles in the English language on precision agriculture practices for increased productivity among smallholder farmers in Sub-Saharan Africa. A total of 7715 articles were retrieved and after screening 128 were reviewed. The results indicate that a number of precision agriculture technologies have been tested under SSA conditions and show promising results. The most promising precision agriculture technologies identified were the use of soil and plant sensors for nutrient and water management, as well as use of satellite imagery, GIS and crop-soil simulation models for site-specific management. These technologies have been shown to be crucial in attainment of appropriate management strategies in terms of efficiency and effectiveness of resource use in SSA. These technologies are important in supporting sustainable agricultural development. Most of these technologies are, however, at the experimental stage, with only South Africa having applied them mainly in large-scale commercial farms. It is concluded that increased precision in input and management practices among SSA smallholder farmers can significantly improve productivity even without extra use of inputs.
\end{abstract}

Keywords: precision agriculture; small-scale farmers; resource use efficiency; Sub-Saharan Africa

\section{Introduction}

Designing soil and crop management practices in relation to variations in the field environment in terms of soil type, moisture and nutrient contents is not new to farmers. This was especially so to small-scale farmers in Sub-Saharan Africa (SSA) before the agrarian revolution when they planned their management practices based on site conditions to optimize the use of soil resources and external inputs. However, after the introduction of inorganic fertilizer use, the practice has been largely abandoned and replaced by blanket recommendations [1]. However, large variation in conditions across locations, farmers, and markets means that "One size fits all" recommendations are inappropriate. The goal of precision agriculture (PA) is to remedy that and the official definition of PA by the International Society for Precision Agriculture is "A management strategy that gathers, processes and analyzes temporal, spatial and individual data and combines them with 
other information to support management decisions according to estimated variability for improved resource use efficiency, productivity, quality, profitability and sustainability of agricultural production".

Precision agriculture has been indicated to involve an increased number of 'correct' decisions per unit area of land per unit time with increases in quantity and/or quality of production and/or the environment along with more efficient use of inputs [2]. This moves the attention from simply spatial resolution to superiority of decisions in both space and time. It also means that it does not imply a particular technology or set of technologies, but that decisions can be made by a range of technologies including soil and crop sensors, global navigation satellite systems (GNSS), such as the global positioning system (GPS), and geographic information systems (GIS), variable rate application (VRA) technologies, etc., as well as being made by humans.

The circumstances under which small-scale farmers in Sub-Saharan Africa are operating are typified by poor access to inputs, suboptimal management practices and market constraints. Standards and precision in input use are often lacking and advanced ways of improving them are not affordable. In addition, government recommendations in most of the SSA countries have not helped much in recognizing the variability that exists between different farms or regions. In most cases, blanket recommendations are made for production regions leading to low efficiencies of the applied inputs [1]. It is however important to note that increased precision in input rates and management practices among these farmers can significantly improve productivity. Like in many parts of the world, PA adoption in SSA has been targeted at addressing the farmers' needs and existing constraints, all aimed at improving productivity of their farms. Such constraints are many and varied, and thus so have the PA technologies that have been used. There exists potential for PA in SSA given that information on agricultural production constraints is available, and technologies to address the constraints have been developed. However, adoption of PA has been quite low in SSA compared to North American and Western Europe [3]. While it is clear that there has been some level of PA uptake in this region, it is not quite clear to what extent it has been taken up. This complicates planning and implementation of other food production programs that may depend on PA technologies in SSA. A study by Nyaga [4] that mapped precision agriculture research in Sub-Saharan Africa countries found that research had been conducted in 25 SSA countries and most of the studies were concentrated in countries with socioeconomic and technological advancement, mainly South Africa followed by Nigeria and Kenya. This review, based on the same body of literature, therefore sought to examine the practicality of PA practices for increased productivity among small scale farmers in SSA. The main focus is on crop and animal protection, growth monitoring, soil mapping (soil type and soil nutrients variations), irrigation/water supply and environmental impact assessment.

The research question is: to what extent are PA technologies practically applicable in SSA smallholder farming systems? Most farming systems in SSA are organized as either farms (mainly small-holder farms) or fields (village fields or home fields) [5].

The objective of this study was therefore to provide a first assessment in English language of the PA technologies that have been tested or are in use in SSA context in order to inform subsequent programs.

The subsequent sections outline the methodology used to gather the information followed by the results obtained, discussion of the results, the conclusions drawn and suggested recommendations.

\section{Materials and Methods}

The method used in this systematic review was adopted from the guidelines for systematic review in environmental management [6]. The study question that needed to be answered was divided up into searchable concepts using the PICO framework:

P-Population;

I-Intervention; 
C-Comparison;

$\mathrm{O}$-Outcome.

In this case, the Population - Smallholder farmers in Sub-Saharan Africa; InterventionUse of precision agriculture technologies (PAT)/concepts; Comparison-No use of PAT technologies/concepts; Outcome-Productivity. A systematic search was conducted for relevant literature published up to July 2018 using the PICO.

\subsection{Literature Searches}

Broad searches of numerous sources were conducted to ensure an unbiased sample of both published and grey literature in March-April 2018 and June-July 2018 [4]. Searches were conducted through: (1) Specialist peer-reviewed publication databases-in order to best capture a broad spectrum of agronomic, environmental or economic literature base (Web of Science: (CABI: CAB abstracts ${ }^{\circledR}$, Core Collection, BIOSIS citation index, Current content connect, Data citation index, MEDLINE ${ }^{\circledR}$ ), SCOPUS, PubMEd, Science4Life, Science direct and Springerlink); (2) Individual journals or repositories-to offer a platform to capture regionally specific or further freely accessible literature (African Journals Online (AJOL), CGSpace-CGIAR and International Society of Precision Agriculture (ISPA). Only articles on precision agriculture technologies or concepts were included.

Database and repository searches were conducted in English language and an asterisk $\left(^{*}\right)$ was used to pick up multiple word endings such as Afric* to pick up Africa and African, etcetera. The following terms (search string) were used in combination to search the online databases; "sub-Saharan Afric*" OR Afric* OR "Afric* countries" AND "precision agriculture" OR "precision farming" OR "site specific farming" OR "climate smart agric*" OR "variable application" OR "Crop sensors" OR "Soil sensors" OR "proximal soil sensors".

However, for African online journals and the repositories (CGSpace-CGIAR and ISPA), the search string was changed due to differences in database functionality to: "precision agriculture" AND "sub-Saharan Africa countries". Use of the search string "smart farming" OR "Site specific farming" OR "Climate smart agriculture" AND "sub-Saharan Africa countries" did not yield any hits.

The results of the searches were imported into the Zotero reference manager software (Corporation for Digital Scholarship, Vienna, VA, USA) and separate folders were created in the main library for each of the databases/website search made. The main library captured the total number of references stored in the various folders and this number was recorded. Using the duplicate function in the Zotero software, duplicates of similar format were removed while duplicates of different file formats were retained (book, book chapter, book review and article). The library was then searched for references with relevant topic according to the following inclusion and exclusion criteria.

\subsection{Inclusion Criteria}

The inclusion criteria were applied by two reviewers to all studies at title and abstract level. Whenever it was not clear whether a study met the criteria, the two reviewers consulted a third reviewer and the matter was resolved. The reviewers discussed the procedures to ensure a consistent understanding of the criteria at both the screening and coding stages.

Relevant studies included all studies that have used precision agriculture (PA) concepts fully or partially in SSA. Besides, for each study to be included, it had to pass the following specific criteria.

1. Relevant intervention: Soil mapping, crop mapping, crop growth monitoring, water and nutrient management, pest control and monitoring, yield predictions, and any other intervention that is intended at improving crop and animal productivity.

2. Relevant subject: PA used in the general areas of agriculture, environment and/or economics, environmental and/or economic outcomes.

3. Relevant outcome: Productivity, income levels, environmental conditions. 
4. Relevant type of study: Any original research study investigating, testing or implementing a PA concept or concepts closely related to PA like precision farming, site-specific farming, conservation farming or climate smart agriculture/farming.

5. Language: Full text written in English.

\subsection{Exclusion Criteria}

The exclusion criteria were applied at both title and abstract level. The studies were excluded at the title level if the title was outside the geographic scope of SSA, the documents did not have a title or the title was not within the general topics of agriculture, environment and economics. At the abstract level, studies were excluded if the abstract was not in English, abstract not available, abstracts outside the general topics of agriculture, environment and economics, abstracts that mention precision agriculture concepts without any supporting data on their application in SSA, abstracts outside the geographical scope of SSA, abstracts with no geographical identity, abstracts within agriculture, environment and economics without precision agriculture data/information, abstract on climate smart, conservation agriculture with no precision agriculture concepts, reviews on precision agriculture in SSA and reviews on precision agriculture outside SSA.

\subsection{Content of the Document}

Types of intervention targeted were those that aimed to improve land, crop and animal productivity through improved resource use. The types of outcomes sought were increased efficiency of input use, improved land productivity, improved yields and accurate prediction of output.

For the types of study: Studies that investigated precision agriculture concepts were considered and only those with data were used in the review.

Language: Studies published in English were used.

Date: All the studies done before July 2018.

Full text in English for the identified articles were then retrieved and used for the review. The resulting references were used to formulate a database.

\section{Results}

\subsection{Tested Technologies and Bottlenecks for Implementation}

A total of 7715 articles were retrieved and after screening for relevance 128 were reviewed in detail. Figure 1 shows a flow diagram of the review detailing the number of studies during the subsequent screening and selection procedures. The results of the review show that a number of PA technologies have been tested and some used for efficient resource use under SSA conditions. They include the use of soil, plant and animal sensors, GIS, remote sensing and application of models [7-18]. For example, the use of sensor technologies for precision crop production by farmers was evaluated in Nigeria where the crops include maize, cassava, cowpea and yams among others, and it was realized that most farmers lack the necessary knowhow for effective use of the technology in crop farming. Furthermore, the extension agents are not equipped with the distinct stages involved in the utilization of the technology [19]. Overall, there seems to be a gap between the actual technical skills of the users and the required technical skills for several PA technologies in SSA. This is likely to be a bottleneck for broad adoption. Potential remedies may be (1) more user-friendly solutions not demanding too much time, effort and knowledge from the user and (2) training of intended users (the farmers and extension workers).

This review has grouped the various studies based on the area of application as outlined below. The references reported in the tables were a select few to demonstrate that precision agriculture is possible under SSA conditions. 


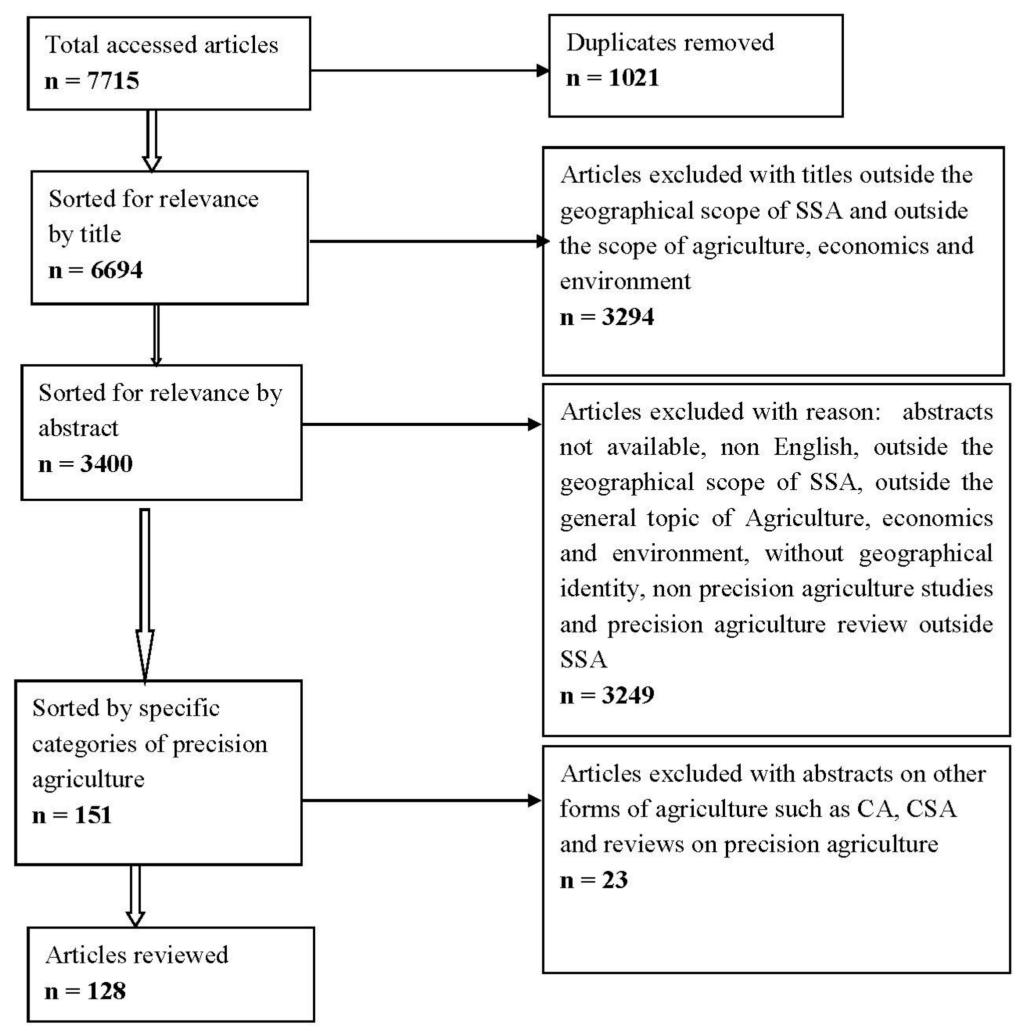

Figure 1. Flow diagram of review of studies on precision agriculture use in Sub-Saharan Africa.

\subsubsection{Plant and Animal Protection}

The articles that have studied precision agriculture technologies in plant and animal protection are shown in Table 1. For crop protection, the tools used include geostatistical techniques in determining spatial distribution of Cassava mosaic disease [20], the use of hyperspectral data in detecting the early stage of Phaeosphaeria leaf spot (PLS) and the severity of maize streak virus infestations in tropical maize [21,22].

Invasive species such as Prosopis juliflora (Sw.) DC are threatening to replace indigenous vegetation with negative impacts on biodiversity and livelihoods in Kenya. Although a few remote sensing studies have been carried out, the accuracy of detection of the species has been poor. Sentinel-2 and Pléiades data were tested for the detection of P. juliflora (invasive spp) and Vachellia spp. (local vegetation) in Kenya [23]. The use of higher spatial resolution Pléiades data gave higher detection accuracies of (out-of-bag (OOB) 0.83 and independent reference of 0.87-0.91) compared to the Sentinel-2 data (OOB of 0.79 and independent reference of $0.80-0.96$ ) in separating Prosopis and Vachellia vegetations. However, given the cost of Pléiades, the use of Sentinel-2 data is a viable alternative given that it is freely available and has been recognized that it can be improved by increasing spectral resolution that compensates for the lack of spatial resolution [23]. In addition, remote sensing has been tested for the monitoring of alien species such as Water Hyacinth (Eichhornia crassipes Mart.) [24].

The use of integrated decision support system for intercropping, a common practice among small-scale farmers in Africa, has been found to provide diagnostic information for $90 \%$ of the common Africa crop diseases [10] while remote sensing has been used successfully in genetic mapping of stripe rust (Puccinia striiformis Westend. f.sp. tritici Erikss.) resistance in wheat [25]. The use of violet diode laser-induced chlorophyll fluorescence has been used to assess mosaic disease severity in cassava (Manihot esculenta Crantz) cultivars [26].

The use of precision agriculture in SSA for animal production is still at the experimental stages. Four studies involving use of sensors [27,28], mapping [29] and site-specific pest 
control [30] were found (Table 1). The sensor technology has been tested on the animal behavior classification and cattle movement in South Africa with results indicating the location and activity of the animals which is useful in fighting stock theft and poaching that are major problems facing South Africa and Kenya.

Table 1. Precision agriculture technologies that have been used for plant and animal protection and disease control.

\begin{tabular}{|c|c|c|c|}
\hline PA Technology & Application & Performance & References \\
\hline Geostatistical techniques & \multirow{6}{*}{$\begin{array}{l}\text { Crop pest and disease } \\
\text { monitoring and detection and } \\
\text { breeding for disease resistance }\end{array}$} & $\begin{array}{l}\text { The models explained } 54 \%, 44 \% \\
\text { and } 22 \% \text { of the variation in Cassava } \\
\text { mosaic disease }\end{array}$ & [20] \\
\hline \multirow[b]{2}{*}{ Remote sensing (Hyperspectral data) } & & $\begin{array}{l}88 \% \text { accuracy in discriminating } \\
\text { healthy maize and early stage of } \\
\text { disease infestation }\end{array}$ & {$[21,22]$} \\
\hline & & $\begin{array}{l}\text { Can be utilized to undertake } \\
\text { multitemporal monitoring of } \\
\text { variable infestation levels of } \\
\text { biological control for } \\
\text { invasive species }\end{array}$ & [24] \\
\hline $\begin{array}{l}\text { Integrated Decision Support System } \\
\text { for Intercropping }\end{array}$ & & $\begin{array}{l}\text { provided } 95 \% \text { diagnosis } \\
\text { information for } 90 \% \text { common } \\
\text { Africa crop diseases }\end{array}$ & [10] \\
\hline Spectral crop sensors & & $\begin{array}{l}\text { Detected the same QTL regions as } \\
\text { described using visual ratings stripe } \\
\text { rust resistance in wheat }\end{array}$ & [25] \\
\hline $\begin{array}{l}\text { Violet diode laser-induced } \\
\text { chlorophyll fluorescence }\end{array}$ & & $\begin{array}{c}\text { Fluorescence data correlated with } \\
\text { cassava mosaic disease severity } \\
\text { levels and with the average yield } \\
\text { per plant }\end{array}$ & [26] \\
\hline Animal borne sensors & \multirow{3}{*}{$\begin{array}{l}\text { Monitoring of animal } \\
\text { behavior and position }\end{array}$} & $82 \%$ accuracy achieved & [27] \\
\hline \multirow{2}{*}{$\begin{array}{l}\text { A wireless sensor network, } \\
\text { Continuous Time Markov Processes } \\
\text { and unmanned aerial vehicles }\end{array}$} & & $\begin{array}{l}\text { Identified the typical behavior of a } \\
\text { cow and determined anomalies } \\
\text { in behavior }\end{array}$ & [28] \\
\hline & & $\begin{array}{l}\text { Accurate monitoring of } \\
\text { cattle movement }\end{array}$ & [8] \\
\hline Geostatistical techniques & \multirow{2}{*}{$\begin{array}{l}\text { Mapping and control of } \\
\text { livestock pests }\end{array}$} & $\begin{array}{l}\text { Identification and monitoring } \\
\text { tsetse hotspots }\end{array}$ & [31] \\
\hline Site-specific application of pesticides & & $\begin{array}{l}\text { The site-specific efficacy of control } \\
\text { was between } 80-100 \% \text { in a period of } \\
3-5 \text { weeks }\end{array}$ & [30] \\
\hline
\end{tabular}

Cattle raiding and cattle rustling are the main challenges faced by farmers and pastoralists in the SSA region due to lack of real time and efficient tracking system. A framework for monitoring cattle movement based on wireless sensor networks (WSN), mobile communication, and unmanned aerial vehicles (UAVs) has been tested [8] (Table 1). Provision of timely information about the location of stolen animals could help quick recovery of the animals and defeat the purpose of cattle rustling as there will be no sufficient time for the rustlers to use the animals for their anticipated intention.

For the control of tsetse (Glossina spp.) and ticks (Rhipicephalus microplus C.), two technologies have been tested, that is, the use of kriging and mapping for the control and monitoring of tsetse in Ethiopia and site-specific treatment for the control of ticks in sheep in South Africa $[30,31]$. The efficacy of site-specific control of ticks in Merino sheep was $100 \%$ while in Dorper it was $>80 \%$. 


\subsubsection{Crop Growth Monitoring}

Remote sensing has been used to assess plant and ecosystem health. The use of remote sensing indicators to determine site quality has been conducted in monitoring Eucalyptus grandis W. Hill. growth [32] while multi-temporal Landsat 8 normalized difference vegetation index (NDVI) anomalies have been used to detect and map inconsistent patches in coffee (Coffea arabica L.) plantations [33] as well as long term evaluation of the green vegetation cover dynamics [34] (Table 2). In addition, it has been used to detect subtle deforestation due to logging in wet and dry savanna woodlands of South Africa [35] as well as predict Pinus patula Schiede ex Schltdl. \& Cham age [36].

Table 2. Precision agriculture technologies that have been used in monitoring crop canopy status.

\begin{tabular}{|c|c|c|c|}
\hline PA Technology & Application & Performance & References \\
\hline $\begin{array}{c}\text { Normalized difference } \\
\text { vegetation index (NDVI) }\end{array}$ & $\begin{array}{l}\text { To discriminate between Eucalyptus } \\
\text { grandis growing on sites with } \\
\text { different qualities }\end{array}$ & $\begin{array}{l}\text { Identified leaf water and } \\
\text { chlorophyll indices as sufficient } \\
\text { indicators of site quality }\end{array}$ & [32] \\
\hline Remote sensing & Canopy copy and age of the plants & $\begin{array}{l}\text { Successfully used to detect subtle } \\
\text { deforestation due to logging as well } \\
\text { as predict Pinus patula age }\end{array}$ & {$[35,36]$} \\
\hline \multirow{2}{*}{$\begin{array}{l}\text { Multi-temporal Landsat } 8 \\
\text { NDVI anomalies }\end{array}$} & $\begin{array}{l}\text { To detect and map inconsistent } \\
\text { patches in coffee (Coffee arabica) }\end{array}$ & \multirow[t]{2}{*}{$80 \%$ accuracy achieved } & \multirow[t]{2}{*}[33,34]{} \\
\hline & Vegetation cover change & & \\
\hline
\end{tabular}

\subsubsection{Irrigation/Water Management}

Table 3 provides a summary of the precision agriculture technologies that have been used in crop water management. Investigations on spatiotemporal variation of moisture indices and their annual trends in Nigeria were investigated [37] and found to be important in the development of appropriate coping and mitigation strategies for areas that do not receive sufficient amounts of rainfall to support high crop yields. Climatic variations and crop water stress based on insufficient soil water and reduced humidity have been studied in tea farms in Kenya [38] and used to predict long term yield of tea in the growing area. A study on the adequacy of irrigation systems found that a system that supplies adequate water to crops had a higher water use efficiency and more yields compared to one that supplied the water uniformly [39]. The use of drones has been tested on irrigation infrastructure planning, which, if adopted could accelerate the planning, design and construction of SSA's irrigation infrastructure [40]. Most of the times, these are poorly designed, build and maintained leading to low irrigation water use efficiency and poor crop yields given that in these regions water is a major limiting factor in improving crop production.

Another technology that has been developed and tested for the management of water stress in crops is wireless sensors for real time plant stress detection [41]. Water stress that occurs due to too much or too little water goes unnoticed by resource poor small-scale farmers in SSA resulting in low crop yield. Due to this situation, a low-cost, real-time wireless sensor technology was developed and tested as an option to reduce water stress and increase yields among these type of farmers [41]. This is a small-scale precision farming approach that is suitable mainly to resource constrained environments with no power and network connectivity that characterize most of SSA farming communities. Besides, WSN technology has been used to optimize drip irrigation in semi-arid environments [42] in Burkina Faso and in the development of a more robust and sustainable irrigation system in Malawi [43].

Additionally, a study involving designing of a GIS for spatial and temporal distribution of irrigation water using drip irrigation system among large scale farms in Tanzania has been conducted [44]. The system was designed to ensure the delivery of the right 
amounts of water based on crop requirements and to monitor the water distribution for uniformity in order to ensure optimum crop yields. This is mainly for precision farming in relation to irrigation water use. The monitoring system generated information on water distribution in the field identifying deficits or excess application spots within the field. Apart from the high technology precision farming practices, farmer practices such as the use of infiltration pits have been shown to improve water management especially in semi-arid environments [45].

Table 3. Precision agriculture technologies that have been used in crop water management.

\begin{tabular}{|c|c|c|c|}
\hline PA Technology & Area of Application & Performance & References \\
\hline Simulation models & \multirow{3}{*}{ Detection of water stress } & $\begin{array}{l}\text { Reported drying tendencies with } \\
40-50 \% \text { of the land area shifting } \\
\text { towards aridity }\end{array}$ & [37] \\
\hline $\begin{array}{l}\text { Thermal time and indices of } \\
\text { water stress }\end{array}$ & & $\begin{array}{l}\text { Accurate prediction of soil water } \\
\text { deficits over } 10 \text { years }\end{array}$ & \multirow{2}{*}[38,41-43]{} \\
\hline Wireless sensor technology & & $\begin{array}{l}\text { Real-time plant moisture } \\
\text { stress detection }\end{array}$ & \\
\hline Precision irrigation & $\begin{array}{l}\text { Adequacy of sprinkler } \\
\text { irrigation performance }\end{array}$ & $\begin{array}{l}\text { Wider nozzle sprinklers lead to } \\
\text { excess irrigation water above the } \\
\text { crop water requirement and uneven } \\
\text { soil moisture distribution }\end{array}$ & [39] \\
\hline Use of UAV-drones & $\begin{array}{l}\text { Planning and building } \\
\text { irrigation infrastructure }\end{array}$ & $\begin{array}{l}1000 \text { ha of land was mapped in a } \\
\text { single day in a region with harsh } \\
\text { terrain and high temperatures }\end{array}$ & [40] \\
\hline $\begin{array}{l}\text { Geographical information } \\
\text { system (GIS) }\end{array}$ & $\begin{array}{l}\text { To monitor spatial and temporal } \\
\text { distribution of irrigation water } \\
\text { using drip irrigation system }\end{array}$ & $\begin{array}{l}\text { Identified deficits or excess } \\
\text { application spots within the field }\end{array}$ & [44] \\
\hline Use of infiltration and planting pits & $\begin{array}{l}\text { To improve water Management } \\
\text { in semi-arid areas }\end{array}$ & $\begin{array}{l}\text { Not useful in improving soil } \\
\text { moisture content in semi-arid areas } \\
\text { but can be used for } \\
\text { erosion management }\end{array}$ & [45] \\
\hline
\end{tabular}

\subsubsection{Mapping Cropping Systems}

Table 4 provides the studies that have been undertaken to map cropping systems. Recognition of different cropping systems has been tested using a machine vision scheme recognition in satellite images in different times, varying illuminations and growing stages [17] of coffee. The results showed that this method can provide correct segmentation of the coffee crop for targeted management. Predictive modeling tool 'Cubist' has also been used to estimate field tree cover used as an integral part of farmed land in temporal scale [46] and provided information on changes that have occurred over time. This information is important in giving direction to interventions geared towards promoting the inclusion of field trees in agricultural systems. For crop mapping, the use of remotely sensed data has been evaluated in West Africa and been found useful in areas with data limitations that frequently hamper accurate crop discrimination [47] while very highresolution (VHR) satellite data have been used to map cropland area among smallholder farmers [48]. In addition, high spatial and temporal resolution RapidEye bio-temporal data have been used to map cropping systems in complex and highly fragmented agroecological landscapes [49]. Simulation models have been used to determine the tree cover within crops and correlation coefficients of 0.88 and 0.77 with absolute mean errors of $1.07 \%$ and $1.03 \%$ tree cover were obtained [46]. While remote sensing was used to distinguish different crops within a field and this improved overall classification accuracies [47].

Besides, link reliability of the WSN as a tool for precision agriculture in SSA has been evaluated using different crops and found that distance between nodes depends on the type 
of vegetation [50]. High resolution (HR) satellite time series with spatial logistic regression modeling have also been used to distinguish land management systems in rangelands [51]. These technologies are useful in supporting precision agriculture in subdivided and disturbed environments such as those found in farming systems in semi-arid SSA.

Table 4. Precision agriculture technologies that have been used to map cropping systems.

\begin{tabular}{|c|c|c|c|}
\hline PA Technology & Area of Application & Performance & References \\
\hline $\begin{array}{l}\text { Machine vision scheme } \\
\text { recognition in satellite images }\end{array}$ & $\begin{array}{l}\text { To distinguish the crops field from } \\
\text { surrounding green vegetation areas }\end{array}$ & $\begin{array}{l}\text { Provided correct segmentation of } \\
\text { vegetation types }\end{array}$ & {$[17,47]$} \\
\hline Simulation models & $\begin{array}{l}\text { To determine the tree cover } \\
\text { within crops }\end{array}$ & $\begin{array}{c}\text { Correlation coefficients of } 0.88 \text { and } \\
0.77 \text { with absolute mean errors of } \\
1.07 \% \text { and } 1.03 \% \text { tree cover } \\
\text { were obtained }\end{array}$ & [46] \\
\hline Remote sensing & To distinguish different crops & $\begin{array}{c}\text { Improved overall } \\
\text { classification accuracies }\end{array}$ & [47] \\
\hline $\begin{array}{l}\text { Wall-to-wall sub-meter } \\
\text { WorldView and moderate } \\
\text { resolution Landsat } 8 \text { imagery }\end{array}$ & $\begin{array}{l}\text { To map cropland among } \\
\text { small-scale farmers }\end{array}$ & $\begin{array}{l}\text { Estimated cropped area with a } \\
\text { commission error of } 5 \% \pm 10 \% \text { and } \\
\text { omission error of } 15 \% \pm 12 \%\end{array}$ & [48] \\
\hline Wireless sensor nodes & $\begin{array}{l}\text { To test the wireless signal in terms } \\
\text { of link reliability, and signal } \\
\text { strength for precision agriculture }\end{array}$ & $\begin{array}{l}\text { Radio propagation foliage loss } \\
\text { models are not optimized for use in } \\
\text { precision agriculture }\end{array}$ & [50] \\
\hline RapidEye & To map maize cropping systems & $\begin{array}{l}\text { An accuracy of } 93 \% \text { was attained for } \\
\text { the land use land cover classification } \\
\text { while }>85 \% \text { accuracy was obtained } \\
\text { for the cropping systems }\end{array}$ & [49] \\
\hline $\begin{array}{l}\text { RapidEye combined with spatial } \\
\text { logistic regression modeling }\end{array}$ & $\begin{array}{l}\text { To discriminate land management } \\
\text { systems in rangelands }\end{array}$ & $\begin{array}{l}\text { Different tenure and management } \\
\text { systems were differentiated within a } \\
\text { 2-year HR image time series }\end{array}$ & [51] \\
\hline
\end{tabular}

\subsubsection{Soil Fertility Mapping}

The use of PA techniques to map soil type as well as soil nutrient status has been conducted in SSA, as shown in Table 5. The use of empirical approach combining nonparametric techniques and spatial methods of parametric model estimation have shown that blanket fertilizer applications commonly used in SSA are inefficient due to site differences [9]. The site differences are not only due to the macronutrient contents but also due to parent material that results in soil property variations [52]. A study on soil nutrient contents in a sandy loam soil have shown that the quantities of both macro- and micronutrients vary depending on the site of the field under study [53] as well as soil types within the farms [54]. In addition, while using geospatial approach, soil nutrients were found to vary among smallholder farms in Ghana [13]. In Nigeria, geo-statistical mapping tools have been used to measure nutrient variability in yam based cropping system among smallholder farms [55] for site-specific fertilizer recommendations. Some farmers in the Sahelian Zone of West Africa use local knowledge to identify fertility variations within the farms [56] while those in Niger define soil types based on location, perceived quality and its relationship with the ecological structure [57], which is a low cost technique to allocate scarce resources amongst smallholder farmers. A study by Barrios [58] on the integration of local and technical knowledge on the identification and classification of soil quality indicators conducted in Kenya, Uganda and Tanzania provides a useful methodology for soil fertility monitoring among smallholder farmers to guide soil fertility management.

Use of a digital soil map taking into account soil fertility constraint has been developed to determine crop suitability for common beans (Phaseolus vulgaris L.) in Tanzania [59] while geoinformatics was used to examine land suitability for different crops as prospects for precision farming in the Savanna River basin in Nigeria for improved yields [60]. The 
study identified areas that were most suitable for maize, cassava, yam or oil palm production. Consequently, RapidEye remote sensing data have been used to map Soil organic carbon (SOC) to enable farm-scale targeting of management interventions [61]. In a study conducted in Cameroon on assessing soil functional properties, Kriged maps were used to identify areas deficient of nutrients [62] and that can be targeted to improve efficient use of fertilizers. Microdosing fertilizer application in millet production systems in Niger has resulted in greater nutrient use efficiency [63]. While in Ghana, a soil diagnostic model was combined with GIS to develop site-specific fertilizer recommendations in cocoa production [64].

Besides, the origin of soil variability have been investigated at regional, local and farm level in agricultural systems of Cameroon [65] to determine appropriate management practices. In addition, spatial distribution and variability of soil properties at catchment-scale has been conducted in Ethiopia and used to produce kriged soil properties maps for sustainable production [66]. Integration of indigenous knowledge, gamma ray spectrometry and high resolution satellite images [67] have been used to capture major soil difference within the territory of a village and used to create village soil maps. This approach allows capture of the major soil differences within a village territory necessary for extension support.

Table 5. Precision agriculture technologies that have been used to map soil fertility and soil types.

\begin{tabular}{|c|c|c|c|}
\hline PA Technology & Application & Performance & References \\
\hline $\begin{array}{l}\text { Non-parametric kernel } \\
\text { density regression }\end{array}$ & \multirow{5}{*}{ Spatial variations in soil fertility } & $\begin{array}{l}\text { confirmed the significance of } \\
\text { within-field soil variability and its } \\
\text { effects on crop yield }\end{array}$ & {$[9,52]$} \\
\hline \multirow[t]{2}{*}{ Geostatistical techniques } & & $\begin{array}{c}\text { The ranges and amounts of the soil } \\
\text { nutrients had a strong } \\
\text { spatial dependence }\end{array}$ & [53] \\
\hline & & $\begin{array}{l}\text { Identified within field variations in } \\
\text { nutrient contents }\end{array}$ & {$[13,55,66]$} \\
\hline Transect walks for soil mapping & & $\begin{array}{l}\text { Identified differences in fertilizer } \\
\text { requirements on different patches of } \\
\text { the field }\end{array}$ & {$[54]$} \\
\hline $\begin{array}{l}\text { Indigenous knowledge combined } \\
\text { with gamma ray spectrometry and } \\
\text { high resolution satellite images }\end{array}$ & & $\begin{array}{l}\text { Development of knowledge-based } \\
\text { extension support }\end{array}$ & {$[56-58,67]$} \\
\hline EcoCrop model-Digital soil maps & \multirow{2}{*}{ Land suitability for specific crops } & \multirow{2}{*}{$\begin{array}{l}\text { Able to identify areas suitable for } \\
\text { specific crops such as common beans } \\
\text { (Phaseolus vulgaris) }\end{array}$} & \multirow{2}{*}[59,60]{} \\
\hline Geoinformatics & & & \\
\hline RapidEye remote sensing & $\begin{array}{l}\text { To develop prediction models } \\
\text { mapping of soil organic carbon }\end{array}$ & $\begin{array}{l}\text { Good model performance and a SOC } \\
\text { map generated }\end{array}$ & [61] \\
\hline Kriged maps & \multirow{2}{*}{$\begin{array}{l}\text { To assess soil } \\
\text { functional properties }\end{array}$} & $\begin{array}{l}\text { Able to identify critical areas for } \\
\text { targeted land management } \\
\text { interventions to improve land quality }\end{array}$ & [62] \\
\hline $\begin{array}{l}\text { Kriging and inverse distance } \\
\text { weighting interpolation }\end{array}$ & & $\begin{array}{l}\text { Able to characterize spatial patterns } \\
\text { soil compaction }\end{array}$ & [68] \\
\hline $\begin{array}{l}\text { Soil diagnostic and geographic } \\
\text { information systems (GIS) }\end{array}$ & $\begin{array}{l}\text { To develop site-specific } \\
\text { fertilizer recommendations }\end{array}$ & $\begin{array}{l}\text { Identified soil groups and sub-groups } \\
\text { and developed site-specific } \\
\text { fertilizer recommendations }\end{array}$ & {$[64,65]$} \\
\hline Near infrared reflectance (NIR) & $\begin{array}{l}\text { For soil sampling and, chemical } \\
\text { and physical analysis }\end{array}$ & $\begin{array}{l}\text { Various soil properties were } \\
\text { adequately estimated, however, } \\
\text { reliability decreased in the order of } \\
\text { clay, organic matter, total } \mathrm{N} \text { and } \\
\mathrm{N} \text {-mineralization rating }\end{array}$ & {$[69,70]$} \\
\hline $\begin{array}{l}\text { Unequal probability proportional to } \\
\text { size sampling }\end{array}$ & $\begin{array}{l}\text { Reducing variability within a } \\
\text { farm management zone }\end{array}$ & $\begin{array}{l}\text { Made proportional sampling } \\
\text { more accurate }\end{array}$ & [71] \\
\hline
\end{tabular}


Kriging and inverse distance weighting interpolation have been tested in SSA [68] and have been found to be able to characterize spatial patterns soil compaction that is useful information for site-specific soil management practices in precision agriculture. Spatial variability provided by kriged contour maps of individual soil nutrients together with cone index is useful in decision making to ensure appropriate management practices that are specific to crop fields [53]. Cone index which is an indicator of soil compaction is the most common type of soil degradation in SSA. However, it is not easy to notice/pick out as its signs are in form of deficiency symptoms that manifest as stunted plant growth, poor plant stands and low crop yields [53]. To predict soil properties, near infrared reflectance has been applied $[69,70]$ while to delineate precision farming management zones, probability and statistical error methods have been used [71].

\subsubsection{Yield Enhancing Studies}

Table 6 outlines technologies that have been tested on enhancing crop yields. An economic analysis to determine the profitability of variable rate application of fertilizer due to site differences as opposed to blanket applications was conducted [72]. The results indicated that higher profits were obtained in variable rate compared to blanket applications. The fact that many smallholder farmers in developing countries own very small sizes of land, it is possible for these farmers to apply site-specific concepts in resource management even without physical maps or diagrams. This can be done through mental maps of for example soil variability and can vary the management or level of input required to improve input efficiency. Besides, variable rate application of $\mathrm{N}$ fertilizer has been shown to result in a yield advantage when compared to uniform rate application in maize production [72]. Besides reducing the area under crop production and using nutrients within the farmers' means has been shown to increase maize production among resource-poor farmers [73].

Table 6. Precision agriculture technologies that have been used to enhance crop yield.

\begin{tabular}{|c|c|c|c|}
\hline PA Technology & Area of Application & Performance & References \\
\hline \multirow{2}{*}{ Variable rate application } & Soil fertility site differences & $\begin{array}{l}\text { Higher profits were obtained in } \\
\text { variable rate compared to } \\
\text { blanket applications }\end{array}$ & [72] \\
\hline & $\begin{array}{l}\text { Reducing the area under crop } \\
\text { production and using nutrients } \\
\text { within the farmers' means }\end{array}$ & $\begin{array}{l}\text { Increased maize production among } \\
\text { resource-poor farmers }\end{array}$ & [73] \\
\hline Conservation agriculture & $\begin{array}{l}\text { Sub-Saharan Africa smallholder } \\
\text { production systems }\end{array}$ & Increased yields & {$[74,75]$} \\
\hline
\end{tabular}

Conservation agriculture, one of the forms of precision agriculture used in SubSaharan Africa smallholder production systems has been shown to increase yields and hence improve food security only when farmers correctly follow the set criteria [74-76]. However, conservation agriculture does not work in increasing yield when practiced by farmers especially women facing other constraints such as labor [74].

\subsubsection{Yield Prediction/Mapping}

Various technologies have been used to predict or map crop yields in SSA (Table 7) To identify limitations in crop production and soil fertility at multiple spatial scales, a monitoring system that combines satellite observations, ecological and socio-economic constraints has been developed for SSA [77]. Provision of timely climate information and improved technical inputs before harvest could help increase crop productivity. The assessment of spatial variability of yield and yield response to fertilizer was conducted on five major crops (cotton, maize, sorghum, millet and peanuts) grown in Mali using high-resolution satellite and unmanned aerial vehicle (UAV) images [78]. The combination of these technologies resulted in identification of spatial variability and accurately assessed 
yield in heterogeneous smallholder conditions. In another study [79], in the Sahel region, a combination of vegetation and thermal indices for cereal yield estimation was investigated and was found to be similar to the official agricultural statistics of the region for 11 years. These technologies are very useful in areas that are inaccessible to ground measurements and can be applied in regions with similar agronomic and climatic characteristics as those used in this study.

Table 7. Precision agriculture technologies that have been used to predict or map crop yield.

\begin{tabular}{|c|c|c|c|}
\hline PA Technology & Area of Application & Performance & References \\
\hline Remote sensing & $\begin{array}{l}\text { To identify limitations in crop } \\
\text { production and soil fertility at } \\
\text { multiple spatial scales }\end{array}$ & $\begin{array}{l}\text { Identified spatial variability and accurately } \\
\text { assessed yield in heterogeneous smallholder } \\
\text { conditions for cotton, maize, sorghum, millet } \\
\text { and peanuts }\end{array}$ & {$[77,78]$} \\
\hline Vegetation and thermal indices & Cereal yield estimation & $\begin{array}{l}\text { Accurate estimation of yield similar to } \\
\text { official agricultural statistics in the Sahel } \\
\text { region for } 11 \text { years }\end{array}$ & [79] \\
\hline Random forest classifier & $\begin{array}{l}\text { Yield variations in } \\
\text { smallholder farming systems }\end{array}$ & $\begin{array}{l}\text { Resulted in the production of a crop type } \\
\text { map with an overall accuracy of } 85 \%\end{array}$ & [80] \\
\hline
\end{tabular}

Yield variations in smallholder farming systems in SSA have been successfully assessed using a random forest classifier [80] that resulted in the production of a crop type map with an overall accuracy of $85 \%$ followed by yield estimation based on linear regressions with vegetation indices (VI) or Leaf Area Index. This is important as it could help to better target agricultural interventions at the farm or village scale for improved productivity.

\section{Discussion}

In SSA countries, PA is a traditional phenomenon that can be improved to achieve high productivity under low technology situation. The small-scale farmers in this region use hand tools and low rates of external input applications. Under these circumstances, PA is equally relevant in the use of scarce resources and external inputs. It is important for example for the farmers to understand the type of fertilizer, the specific site and amounts required to achieve the best possible fertilizer efficiency and returns to cash investment [81]. The transfer of advice and recommendations are also crucial, and new digital solutions are expected to become more important in the near future [82]. Therefore, applications of technologies that are efficient and effective in resource use are vital. Spatial dimensions of agricultural production are mostly applicable to farmers in SSA because large yield differences occur within short distances between and within farms. These have been demonstrated by Florax [81].

Although in most parts of SSA smallholder farmers lack access to the more sophisticated tools for site-specific crop management, some of them use indigenous knowledge to identify variations within their farms. Although this is a rudimentary way to identify soil fertility variations within the farms, it is useful in efficient use of the limited resources to improve crop production [56]. Unfortunately, government nutrient recommendations in most of these SSA countries have also not helped much in recognizing the spatial distribution of soil nutrients. In most cases, blanket fertilizer recommendations are made for production regions leading to low efficiencies of the applied nutrients [13]. The maps obtained by for example $[13,52,55,64,65,83]$ on nutrient variations within field and landscape level forms a basis for fertilizer recommendations in SSA that are site specific. Recent developments in openly available agricultural decision support systems for precision agriculture, have enabled direct access to near-real-time satellite data at the farm level (e.g., CropSAT.com; Ref. [84] is at least relevant for larger fields (depending on the spatial resolution of the images) and for farmers with Internet access). 
The second limiting resource amongst smallholder farming systems in SSA is water. Due to this, smallholder farmers require appropriate coping and mitigation strategies for areas that do not receive sufficient amounts of rainfall to support high crop yields [37]. Climatic variations and crop water stress based on insufficient soil water and reduced humidity have been studied [38] and predictions made on crop yield. It has been documented that adequate water supply is more important than uniform water supply by irrigation systems for improved water use efficiency [39]. Hence, emphasis should be placed on ensuring adequate water supply for optimum growth and yield. Integration of technologies such as the use of drones and real-time wireless sensor technology will be advantageous in accelerating planning, design and construction of SSA's irrigation systems [40]. This will improve irrigation water use efficiency and increase crop yields in SSA where water is a major limiting factor in improving crop production.

Besides, the use of GIS for spatial and temporal distribution of irrigation water to ensure adequate supply of water based on crop requirements will support efficient use of water and ensure optimum crop yields [44]. This is mainly for precision farming in relation to irrigation water use. This type of system generates information on water distribution in the field identifying deficits or excess application spots within the field. As the high technology precision farming practices are being introduced to support PA in SSA smallholder farms, indigenous knowledge should not be ignored especially in semiarid environments [45].

The use of PA technologies in SSA for animal production is still at the experimental stages mainly involving the use of sensors and geostatistical techniques. The sensor technology has been tested on the animal behavior classification and cattle movement while geostatistical techniques have been used for the control and monitoring of animal pests $[30,31]$. Much still needs to be done on PA in smallholder animal production systems in SSA for resource use efficiency.

In smallholder farming systems in SSA, standards and precision in input use are often lacking and advanced ways of improving them are not affordable. Besides, government recommendations do not recognize the variability that exists between different farms or regions [1]. Increased precision in input rates and management practices among these farmers can significantly improve productivity even without extra use of inputs. This information is important to inform planning and implementation of subsequent programs in SSA aimed at improving resource use efficiency.

\section{Conclusions}

A number of precision agriculture (PA) technologies have been tested in SSA with promising results. The most promising PA technologies for SSA include the use of soil and plant sensors for soil nutrient and water status mapping, and satellite imagery for crop mapping. The use of GIS and crop-soil simulation models has been tested to derive decision support for site-specific management of crops. Most of these technologies are however at experimental stage with only South Africa having applied them mainly in largescale commercial farms. For smallholder animal production systems, limited information exists on the use of PA technologies in SSA. The documented evidence indicated that these practices are still at the experimental stages mainly involving the use of sensors and geostatistical techniques. Much still needs to be done on PA in smallholder animal production systems in SSA for resource use efficiency.

It was obvious that some tested technologies were not provided in a user-friendly way but required advanced technical knowledge from the users. This and other bottlenecks need to be remedied before any broad implementation of PA technologies in small-scale agriculture in SSA can take place. There is no known current application of the technologies amongst small-scale farmers that was identified in the current review. Nevertheless, these technologies are important in supporting sustainable agricultural development in SSA that is mainly characterized by small-scale farmers who form the highest percentage especially in agricultural production. 
The technologies will be key in decision making on resource allocation and management based on information and knowledge. For SSA, this will help to stop blanket recommendations and enable efficient use of scarce resources for improved productivity. Implementation of precision agriculture technologies in smallholder farming systems in SSA can drastically improve overall efficiency of input use and hence increased yields without extra use of inputs. Specifically, water and nutrient use efficiency will increase tremendously given they are often limiting in these systems. Adoption of PA technologies by smallholder farmers will enhance productive inputs for the farmers (fertilizers, water, crop protection items), decreasing expenses, and minimizing the negative environmental influence.

Precision agriculture is known to use inputs in a judicious manner to improve productivity and resource efficiency, reduce costs and minimize negative environmental impacts. For the developed countries, PA involves use of technologies such as satellite imagery, information communication technology and geospatial tools. Technologies used to collect, analyze and document data on productivity levels, soil conditions in different parts of the field for both nutrient and water management. In developing countries such as those found in SSA, there is little or no use of western PA technology due to limitations of access to the technologies, capacity and financial constraints. However, it is possible for farmers in these regions to explore the means and resources available to them in order to increase agricultural productivity. This can be done through prudent and targeted application of inputs such as microdosing, soil testing and proper spacing and utilization of indigenous knowledge. These will enable the farmers to increase yields other than application methods such as broadcasting of, e.g., fertilizer and seeds. The targeted application can also help the smallholder farmers in SSA to be more competitive by lowering the production costs.

For a complete review of PA in SSA, there is need to conduct a similar review in the French language, given that there are a number of countries in SSA that publish their research in French.

Author Contributions: Conceptualization, C.M.O., J.M.N., J.W. and M.S.; methodology, C.M.O. and J.M.N.; validation, J.W., K.P. and M.S.; formal analysis, C.M.O. and J.M.N.; investigation, C.M.O. and J.M.N.; writing-original draft preparation, C.M.O.; writing-review and editing, C.M.O., J.M.N., J.W., K.P. and M.S. All authors have read and agreed to the published version of the manuscript.

Funding: This research was funded by the Swedish International Development Cooperation Agency (Sida)-AgriFoSe2030 program.

Institutional Review Board Statement: Not applicable.

Informed Consent Statement: Not applicable.

Data Availability Statement: No new data were created or analyzed in this study. Data sharing is not applicable to this article.

Conflicts of Interest: The authors declare no conflict of interest. The funders had no role in the design of the study; in the collection, analyses, or interpretation of data; in the writing of the manuscript, or in the decision to publish the results.

\section{References}

1. Soropa, G.; Nyamangara, J.; Nyakatawa, E.Z. Nutrient status of sandy soils in smallholder areas of Zimbabwe and the need to develop site-specific fertiliser recommendations for sustainable crop intensification. S. Afr. J. Plant Soil. 2019, 36, 149-151. [CrossRef]

2. McBratney, A.; Whelan, B.; Ancev, T.; Bouma, J. Future directions of precision agriculture. Precis. Agric. 2005, 6, 7-23. [CrossRef]

3. Lowenberg-DeBoer, J.; Erickson, B. Setting the Record Straight on Precision Agriculture Adoption. Agron. J. 2019, 111, 1552-1569. [CrossRef]

4. Nyaga, J.M.; Onyango, C.M.; Wetterlind, J.; Söderström, M. Precision agriculture research in sub-Saharan Africa countries: A systematic map. Precis. Agric. under review.

5. Lowder, S.K.; Skoet, J.; Raney, T. The Number, Size, and Distribution of Farms, Smallholder Farms, and Family Farms Worldwide. World Dev. 2016, 87, 16-29. [CrossRef]

6. Centre for Evidence Based Conservation. Guidelines for Systematic Reviews in Environmental Management, version 4.2; Collaboration for Environmental Evidence: Bangor, UK, 2013. 
7. Were, K.; Bui, D.T.; Dick, O.B.; Singh, B.R. A comparative assessment of support vector regression, artificial neural networks, and random forests for predicting and mapping soil organic carbon stocks across an Afromontane landscape. Ecol. Indic. 2015, 52, 394-403. [CrossRef]

8. Nkwari, P.K.M.; Rimer, S.; Paul, B.S.; Ferreira, H. Heterogeneous wireless network based on Wi-Fi and ZigBee for cattle monitoring. In Proceedings of the 2015 IST-Africa Conference, Lilongwe, Malawi, 6-8 May 2015; pp. 1-9.

9. Voortman, R.L.; Brouwer, J. An empirical analysis of the simultaneous effects of nitrogen, phosphorus and potassium in millet production on spatially variable fields in SW Niger. Nutr. Cycl. Agroecosyst. 2003, 66, 143-164. [CrossRef]

10. Sodiya, A.S.; Akinwale, A.T.; Okeleye, K.A.; Emmanuel, J.A. An Integrated Decision Support System for Intercropping. Int. J. Decis. Support. Syst. Technol. 2010, 2, 51-66. [CrossRef]

11. Adnan, A.A.; Jibrin, J.M.; Kamara, A.; Abdulrahman, B.L.; Shaibu, A.S.; Garba, I.I. CERES-maize model for determining the optimum planting dates of early maturing maize varieties in northern Nigeria. Front. Plant Sci. 2017, 8, 1118. [CrossRef]

12. Amouzou, K.A.; Naab, J.B.; Lamers, J.P.A.; Becker, M. CERES-Maize and CERES-Sorghum for modeling growth, nitrogen and phosphorus uptake, and soil moisture dynamics in the dry savanna of West Africa. Field Crop. Res. 2018, 217, 134-149. [CrossRef]

13. Antwi, M.; Duker, A.A.; Fosu, M.; Abaidoo, R.C. Geospatial approach to study the spatial distribution of major soil nutrients in the Northern region of Ghana. Cogent. Geosci. 2016, 2, 1201906. [CrossRef]

14. Landmanna, T.; Piiroinen, R.; Makoriad, D.M.; Abdel-Rahman, E.M.; Makau, S.; Pellikka, P.; Raina, S.K. Application of hyperspectral remote sensing for flower mapping in African savannas. Remote Sens. Environ. 2015, 166, 50-60. [CrossRef]

15. Maine, N.; Nell, W.T.; Lowenberg-DeBoer, J.; Alemu, Z.G. Economic analysis of phosphorus applications under variable and single-rate applications in the Bothaville district. Agrekon 2007, 46, 532-547. [CrossRef]

16. Omer, G.; Mutanga, O.; Abdel-Rahman, E.M.; Adam, E. Empirical prediction of leaf area index (LAI) of endangered tree species in intact and fragmented indigenous forests ecosystems using WorldView-2 data and two robust machine learning algorithms. Remote Sens. 2016, 8, 4. [CrossRef]

17. Tsai, D.-M.; Chen, W.-L. Coffee plantation area recognition in satellite images using Fourier transform. Comput. Electron. Agric. 2017, 135, 115-127. [CrossRef]

18. Zurita-Milla, R.; Izquierdo-Verdiguier, E.; De By, R.A. Identifying crops in smallholder farms using time series of WorldView-2 images. In Proceedings of the 2017 9th International Workshop on the Analysis of Multitemporal Remote Sensing Images (MultiTemp), Bruges, Belgium, 26-29 June 2017; IEEE: Piscataway, NJ, USA, 2017. [CrossRef]

19. Ifeanyieze, F.O.; Ikehi, M.E.; Isiwu, E. Techniques in utilizing remote sensor technology for precision crop production by farmers as climate change adaptation strategy in Nigeria. Agric. Sci. 2014, 5, 1476-1482. [CrossRef]

20. Bouwmeester, H.; Heuvelink, G.B.M.; Legg, J.P.; Stoorvogel, J.J. Comparison of disease patterns assessed by three independent surveys of cassava mosaic virus disease in Rwanda and Burundi. Plant Pathol. 2012, 61, 399-412. [CrossRef]

21. Adam, E.; Deng, H.; Odindi, J.; Abdel-Rahman, E.M.; Mutanga, O. Detecting the early stage of phaeosphaeria leaf spot infestations in maize crop using in situ hyperspectral data and guided regularized random forest algorithm. J. Spectrosc. 2017, 2017. [CrossRef]

22. Dhau, I.; Adam, E.; Mutanga, O.; Ayisi, K.K. Detecting the severity of maize streak virus infestations in maize crop using in situ hyperspectral data. Trans. R. Soc. S. Afr. 2018, 73, 8-15. [CrossRef]

23. Ng, W.-T.; Rima, P.; Einzmann, K.; Immitzer, M.; Atzberger, C.; Eckert, S. Assessing the potential of sentinel-2 and pléiades data for the detection of Prosopis and Vachellia spp. In Kenya. Remote Sens. 2017, 9, 74. [CrossRef]

24. Agjee, N.H.; Ismail, R.; Mutanga, O. Identifying relevant hyperspectral bands using Boruta: A temporal analysis of water hyacinth biocontrol. J. Appl. Remote Sens. 2016, 10, 042002. [CrossRef]

25. Pretorius, Z.A.; Lan, C.X.; Prins, R.; Knight, V.; McLaren, N.W.; Singh, R.P.; Bender, C.M.; Kloppers, F.J. Application of remote sensing to identify adult plant resistance loci to stripe rust in two bread wheat mapping populations. Precis. Agric. 2017, 18, 411-428. [CrossRef]

26. Anderson, B.; Eghan, M.J.; Asare-Bediako, E.; Buah-Bassuah, P.K. Violet diode laser-induced chlorophyll fluorescence: A tool for assessing mosaic disease severity in cassava (Manihot esculenta Crantz) cultivars. Environ. Technol. 2012, 33, 367-372. [CrossRef] [PubMed]

27. Le Roux, S.; Wolhuter, R.; Niesler, T. An overview of automatic behaviour classification for animal-borne sensor applications in South Africa. In Proceedings of the ACM Multimedia 2017 Workshop on South African Academic Participation, SAWACMMM '17, Mountain View, CA, USA, 23-27 October 2017; pp. 15-19. [CrossRef]

28. Nkwari, P.K.M.; Rimer, S.; Paul, B.S. Cattle monitoring system using wireless sensor network in order to prevent cattle rustling In Proceedings of the IST-Africa 2014 Conference, Mauritius, 6-9 May 2014; pp. 1-10.

29. Sciarretta, A.; Zinni, A.; Mazzocchetti, A.; Trematerra, P. Spatial Analysis of Lobesia botrana (Lepidoptera: Tortricidae) Male Population in a Mediterranean Agricultural Landscape in Central Italy. Environ. Entomol. 2008, 37, 382-390. [CrossRef] [PubMed]

30. Fourie, L.J.; Kok, D.J.; Peter, R.J. Influence of sheep breed and application site on the efficacy of a flumethrin pour-on formulation against ticks. J. S. Afr. Vet. Assoc. 2001, 72, 143-146. [CrossRef] [PubMed]

31. Sciarretta, A.; Girma, M.; Tikubet, G.; Belayehun, L.; Ballo, S.; Baumgärtner, J. Development of an Adaptive Tsetse Population Management Scheme for the Luke Community, Ethiopia. J. Med. Entomol. 2005, 42, 1006-1019. [CrossRef] [PubMed]

32. Cho, M.A.; Aardt, J.V.; Majeke, B.; Main, R. Evaluating the seasonality of remote sensing indicators of system state for Eucalyptus grandis growing on different site qualities. In Proceedings of the IGARSS 2008-2008 IEEE International Geoscience and Remote Sensing Symposium, Boston, MA, USA, 7-11 July 2008; pp. III487-III490. 
33. Chemura, A.; Mutanga, O.; Dube, T. Integrating age in the detection and mapping of incongruous patches in coffee (Coffea arabica) plantations using multi-temporal Landsat 8 NDVI anomalies. Int. J. Appl. Earth Obs. Geoinf. 2017, 57, 1-13. [CrossRef]

34. Folega, F.; Agbelessessi, W.Y.; Dourma, M.; Wala, K.; Batawila, K.; Seburanga, J.L.; Zhang, C.; Peng, D.; Zhao, X.-H.; Akpagana, $\mathrm{K}$. Long term evaluation of green vegetation cover dynamic in the Atacora Mountain chain (Togo) and its relation to carbon sequestration in West Africa. J. Mt. Sci. 2015, 12, 921-934. [CrossRef]

35. Mapfumo, R.B.; Murwira, A.; Masocha, M.; Andriani, R. Detection of subtle deforestation due to logging using satellite remote sensing in wet and dry savanna woodlands of Southern Africa. Geocarto Int. 2017, 32, 514-530. [CrossRef]

36. Dye, M.; Mutanga, O.; Ismail, R. Examining the utility of random forest and AISA Eagle hyperspectral image data to predict Pinus patula age in KwaZulu-Natal, South Africa. Geocarto Int. 2011, 26, 275-289. [CrossRef]

37. Oguntunde, P.G.; Lischeid, G.; Abiodun, B.J.; Dietrich, O. Analysis of long-term dry and wet conditions over Nigeria. Int. J. Climatol. 2017, 37, 3577-3586. [CrossRef]

38. Stephens, W.; Othieno, C.O.; Carr, M.K.V. Climate and weather variability at the Tea Research Foundation of Kenya. Agric. For. Meteorol. 1992, 61, 219-235. [CrossRef]

39. Dinka, M.O. Evaluating the Adequacy Performance of Sprinkler Irrigation Systems at Finchaa Sugar Cane Plantation, Eastern Wollega Zone (Ethiopia). Irrig. Drain. 2016, 65, 537-548. [CrossRef]

40. CT Update: Drones for Agriculture. ICT Update 2016. Available online: https://cgspace.cgiar.org/handle/10568/89779 (accessed on 23 March 2018).

41. Zeni, M.; Ondula, E.; Mbitiru, R.; Nyambura, A.; Samuel, L.; Fleming, K.; Weldemariam, K. Low-power low-cost wireless sensors for real-time plant stress detection. In Proceedings of the 2015 Annual Symposium on Computing for Development, London, UK, 1-2 December 2015; pp. 51-59.

42. Müller, T.; Ranquet, C.B.; Perona, P. Optimizing drip irrigation for eggplant crops in semi-arid zones using evolving thresholds. Agric. Water Manag. 2016, 177, 54-65. [CrossRef]

43. Mafuta, M.; Zennaro, M.; Bagula, A.; Ault, G.; Gombachika, H.; Chadza, T. Successful deployment of a wireless sensor network for precision agriculture in Malawi. Int. J. Distrib. Sens. Netw. 2013, 2013, 1-13. [CrossRef]

44. Fue, K.G.; Sanga, C. Remote scheduling system for drip irrigation system using geographic information system. J. Geogr. Inf. Syst. 2015, 7, 551-563. [CrossRef]

45. Nyakudya, I.W.; Stroosnijder, L.; Nyagumbo, I. Infiltration and planting pits for improved water management and maize yield in semi-arid Zimbabwe. Agric. Water Manag. 2014, 141, 30-46. [CrossRef]

46. Herrmann, S.M.; Wickhorst, A.J.; Marsh, S.E. Estimation of tree cover in an agricultural parkland of senegal using rule-based regression tree modeling. Remote Sens. 2013, 5, 4900-4918. [CrossRef]

47. Forkuor, G.; Conrad, C.; Thiel, M.; Landmann, T.; Barry, B. Evaluating the sequential masking classification approach for improving crop discrimination in the Sudanian Savanna of West Africa. Comput. Electron. Agric. 2015, 118, 380-389. [CrossRef]

48. McCarty, J.L.; Neigh, C.S.R.; Carroll, M.L.; Wooten, M.R. Extracting smallholder cropped area in Tigray, Ethiopia with wall-to-wall sub-meter WorldView and moderate resolution Landsat 8 imagery. Remote Sens. Environ. 2017, 202, 142-151. [CrossRef]

49. Kyalo, R.; Abdel-Rahman, E.M.; Subramanian, S.; Nyasani, J.O.; Thiel, M.; Jozani, H.; Borgemeister, C.; Landmann, T. Maize cropping systems mapping using rapideye observations in agro-ecological landscapes in Kenya. Sensors 2017, $17,2537$.

50. Ngandu, G.; Nomatungulula, C.; Rimer, S.; Paul, B.S.; Ouahada, K.; Twala, B. Evaluating effect of foliage on link reliability of wireless signal. In Proceedings of the 2013 IEEE International Conference on Industrial Technology (ICIT), Cape Town, South Africa, 25-28 February 2013; pp. 1528-1533.

51. Parplies, A.; Dubovyk, O.; Tewes, A.; Mund, J.-P.; Schellberg, J. Phenomapping of rangelands in South Africa using time series of RapidEye data. Int. J. Appl. Earth Obs. Geoinf. 2016, 53, 90-102. [CrossRef]

52. Voortman, R.L.; Brouwer, J.; Albersen, P.J. Characterization of spatial soil variability and its effect on Millet yield on SudanoSahelian coversands in SW Niger. Geoderma 2004, 121, 65-82. [CrossRef]

53. Lomeling, D. Correlating the spatial distribution of some macro- and micro nutrients with Cone Index in a sandy loam soil (Eutric leptosol). Int. J. AgriSci. 2014, 4, 89-101.

54. Tabu, I.M.; Obura, R.K.; Bationo, A.; Mumera, L. Effect of soil fertility management and nitrogen fertilizer rate on maize yield in small holder farmers fields. J. Agron. 2006, 5, 191-195.

55. Jemo, M.; Jayeoba, O.J.; Alabi, T.; Montes, A.L. Geostatistical mapping of soil fertility constraints for yam based cropping systems of North-central and Southeast Nigeria. Geoderma Reg. 2014, 2-3, 102-109. [CrossRef]

56. Hayashi, K.; Hayashi, E.T.; Fatondji, D. Evaluation of the Indigenous Use of the Weed Sida cordifolia L. in the Sahelian Zone of West Africa. Jpn. Agric. Res. Q. JARQ 2013, 47, 389-396. [CrossRef]

57. Osbahr, H.; Allan, C. Indigenous knowledge of soil fertility management in southwest Niger. Geoderma 2003, 111, 457-479. [CrossRef]

58. Barriosa, E.; Delveb, R.J.; Bekundac, M.; Mowod, J.; Agundae, J.; Ramischf, J.; Trejog, M.T.; Thomas, R.J. Indicators of soil quality: A South-South development of a methodological guide for linking local and technical knowledge. Geoderma 2006, 135, 248-259. [CrossRef]

59. Piikki, K.; Winowiecki, L.; Vågen, T.-G.; Ramirez-Villegas, J.; Söderström, M. Improvement of spatial modelling of crop suitability using a new digital soil map of Tanzania. S. Afr. J. Plant Soil 2017, 34, 243-254. [CrossRef] 
60. Rilwani, M.L.; Ikhuoria, I.A. Prospects for geoinformatics-based precision farming in the Savanna River basin, Nigeria. Int. J. Remote Sens. 2011, 32, 3539-3549. [CrossRef]

61. Winowiecki, L.; Vågen, T.-G.; Massawe, B.; Jelinski, N.A.; Lyamchai, C.; Sayula, G.; Msoka, E. Landscape-scale variability of soil health indicators: Effects of cultivation on soil organic carbon in the Usambara Mountains of Tanzania. Nutr. Cycl. Agroecosyst. 2016, 105, 263-274. [CrossRef]

62. Takoutsing, B.; Martín, J.A.R.; Weber, J.C.; Shepherd, K.; Sila, A.; Tondoh, J. Landscape approach to assess key soil functional properties in the highlands of Cameroon: Repercussions of spatial relationships for land management interventions. J. Geochem. Explor. 2017, 178, 35-44. [CrossRef]

63. Twomlow, S.; Urolov, J.C.; Jenrich, M.; Oldrieve, B. Lessons from the field-Zimbabwe's conservation agriculture task force. J. SAT Agric. Res. 2008, 6, 1-11.

64. Snoeck, D.; Afrifa, A.A.; Ofori-Frimpong, K.; Boateng, E.; Abekoe, M.K. Mapping fertilizer recommendations for cocoa Production in Ghana using soil siagnostic and GIS tools. West. Afr. J. Appl. Ecol. 2010, 17, 97-107.

65. Yemefack, M.; Rossiter, D.G.; Njomgang, R. Multi-scale characterization of soil variability within an agricultural landscape mosaic system in southern Cameroon. Geoderma 2005, 125, 117-143. [CrossRef]

66. Tesfahunegn, G.B.; Tamene, L.; Vlek, P.L.G. Catchment-scale spatial variability of soil properties and implications on site-specific soil management in northern Ethiopia. Soil Tillage Res. 2011, 117, 124-139. [CrossRef]

67. Reinhardt, N.; Herrmann, L. Fusion of indigenous knowledge and gamma spectrometry for soil mapping to support knowledgebased extension in Tanzania. Food Secur. 2017, 9, 1271-1284. [CrossRef]

68. Lomeling, D.; Lasu, D.M. Spatial Patterns of Penetration Resistance and Soil Moisture Distribution in a Sandy Loam Soil (Eutric leptosol). Int. J. Soil Sci. 2015, 10, 130-141. [CrossRef]

69. Winowiecki, L.A.; Vågen, T.-G.; Boeckx, P.; Dungait, J.A.J. Landscape-scale assessments of stable carbon isotopes in soil under diverse vegetation classes in East Africa: Application of near-infrared spectroscopy. Plant Soil 2017, 421, 259-272. [CrossRef]

70. Van Vuuren, J.A.J.; Meyer, J.H.; Claassens, A.S. Potential use of near infrared reflectance monitoring in precision agriculture. Commun. Soil Sci. Plant Anal. 2006, 37, 2171-2184. [CrossRef]

71. Sirakalala, K.; Moshia, M.E. Probability and statistical error of soil sampling on patches assimilated during delineation of precision farming management zones. J. Agric. Sci. Technol. B 2014, 4, 440-448.

72. Maine, N.; Lowenberg-DeBoer, J.; Nell, W.T.; Alemu, Z.G. Impact of variable-rate application of nitrogen on yield and profit: A case study from South Africa. Precis. Agric. 2010, 11, 448-463. [CrossRef]

73. Rusinamhodzi, L.; Dahlin, S.; Corbeels, M. Living within their means: Reallocation of farm resources can help smallholder farmers improve crop yields and soil fertility. Agric. Ecosyst. Environ. 2016, 216, 125-136. [CrossRef]

74. Hove, M.; Gweme, T. Women's food security and conservation farming in Zaka District-Zimbabwe. J. Arid Environ. 2018, 149, 18-29. [CrossRef]

75. Thierfelder, C.; Rusinamhodzi, L.; Setimela, P.; Walker, F.; Eash, N.S. Conservation agriculture and drought-tolerant germplasm: Reaping the benefits of climate-smart agriculture technologies in central Mozambique. Renew. Agric. Food Syst. 2016, 31, 414-428. [CrossRef]

76. Ologeh, I.O.; Akarakiri, J.B.; Adesina, F.A. Promoting Climate Smart Agriculture Through Space Technology in Nigeria. In Innovation in Climate Change Adaptation; Springer: Cham, Switzerland, 2016; pp. 99-112.

77. Rosa, M.F.; Bonham, C.A.; Dempewolf, J.; Arakwiye, B. An integrated approach to monitoring ecosystem services and agriculture: Implications for sustainable agricultural intensification in Rwanda. Environ. Monit. Assess. 2017, 189, 15. [CrossRef]

78. Schut, A.G.T.; Traore, P.C.S.; Blaes, X.; de By, R.A. Assessing yield and fertilizer response in heterogeneous smallholder fields with UAVs and satellites. Field Crop. Res. 2018, 221, 98-107. [CrossRef]

79. Leroux, L.; Baron, C.; Zoungrana, B.; Traore, S.B.; Lo Seen, D.; Begue, A. Crop Monitoring Using Vegetation and Thermal Indices for Yield Estimates: Case Study of a Rainfed Cereal in Semi-Arid West Africa. IEEE J. Sel. Top. Appl. Earth Obs. Remote Sens. 2016, 9, 347-362. [CrossRef]

80. Lambert, M.-J.; Blaes, X.; Traore, P.S.; Defourny, P. Estimate yield at parcel level from S2 time serie in sub-Saharan smallholder farming systems. Presented at the 2017 9th International Workshop on the Analysis of Multitemporal Remote Sensing Images, (MultiTemp), Bruges, Belgium, 27-29 June 2017; pp. 1-7.

81. Florax, R.J.G.M.; Voortman, R.L.; Brouwer, J. Spatial dimensions of precision agriculture: A spatial econometric analysis of millet yield on Sahelian coversands. Agric. Econ. 2002, 27, 425-443. [CrossRef]

82. Fabregas, R.; Kremer, M.; Schilbach, F. Realizing the potential of digital development: The case of agricultural advice. Science 2019, 366, eaay3038. [CrossRef] [PubMed]

83. Piikki, K.; Söderström, M.; Eriksson, J.; Muturi, J.J.; Muthee, P.I.; Wetterlind, J.; Lund, E. Performance Evaluation of Proximal Sensors for Soil Assessment in Smallholder Farms in Embu County, Kenya. Sensors 2016, 16, 1950. [CrossRef] [PubMed]

84. Alshihabi, O.; Piikki, K.; Söderström, M.A. Decision Support System for Practical Use of Satellite Images in Precision Agriculture. In Advances in Smart Technologies Applications and Case Studies; Springer: Cham, Switzerland, 2019; pp. 415-421. 